\title{
ПРОБЛЕМАТИКА ПСИХОЛОГИИ ТВОРЧЕСТВА В ТЕАТРАЛЬНОМ ИСКУССТВЕ
}

\author{
А. А. Оганов \\ Высшее театральное училище (институт) им. М. С. Щепкина
}

Аннотация: В статье обосновывается значимость психологической теории при рассмотрении природы театрального искусства, игры актера. В тексте названы узловые вопросы и основная проблематика психологии творчества, наиболее востребованные в актерской профессии.

Текст доклада автора на Всероссийской научной конференции «Культура между Логосом и Мифом: к проблеме бессознательного (к 80-летию А. Э. Воскобойникова)», которая прошла в Московском гуманитарном университете 26-27 октября 2017 года.

Ключевые слова: театральное искусство; психология творчества; изобразительно-выразительные средства театра; психологическая рефлексия

\section{ISSUES OF CREATIVITY PSYCHOLOGY IN THEATRICAL ART}

\author{
A. A. Oganov \\ Mikhail Shchepkin Higher Theatre School (Institute)
}

Abstract: The paper substantiates the significance of psychological theory when considering the nature of theatrical art and acting. The text includes the focal points and main issues of creativity psychology that are in great demand in the acting profession.

The text of the author's speech at the All-Russian Scientific Conference "Culture between Logos and Myth: on the Issue of the Unconscious (dedicated to the 80th anniversary of A. E. Voskoboynikov)", which was held at Moscow University for the Humanities on 26-27 October 2017.

Keywords: theatrical art; creativity psychology; visual and expressive means of the theatre; psychological reflection

Знакомство с широко известными текстами выдающихся деятелей театрального искусства, теоретическими работами ученых-психологов убеждает в том, что психология творчества является важной методологической основой профессиональной подготовки актеров сценического искусства. В значительной мере это касается теории и практики театральной педагогики, которую нельзя помыслить в отрыве от психологической науки. И 
Научные труды Московского гуманитарного университета 2018 № 3

тем не менее значение этой классической компоненты в современном театральном образовании явно недооценивается.

Целью написания данной статьи является обоснование роли психологической теории в осмыслении основ театрального творчества и его практической реализации. При всем видовом многообразии искусства именно в театрально-художественной практике наиболее ощутима потребность в психологическом осмыслении творческого процесса. Здесь дают о себе знать, по меньшей мере, два решающих обстоятельства.

Во-первых, спектакль - это живое общение с аудиторией, вследствие чего акт творчества полностью совпадает с бытийностью театрального произведения. Иными словами, сценическое исполнение и есть собственно процессуальное осуществление произведения. Абсолютное пространственно-временно единство образует их полную слитность. Сценическое действие происходит здесь и сейчас, и никогда больше не повторится. Таково условие актерского существования, его сиюминутного поведения переживаний и чувствований. За всем этим сложный комплекс психофизиологических процессов, подчас, стихийных, трудно поддающихся осознанию. В схождении двух человеческих ипостасей - персонажа и актера, последний, исполняя роль, в реальности проживает короткий промежуток своей жизни.

Эта жизнь на сцене несопоставимо насыщена, интенсивна, предельно сжата, в отличие от повседневной, обыденной, что за пределами сцены. Психофизиологическое напряжение, испытываемые эмоции и страсти достигают критического накала. И все это усугубляется всепроникающим живым «дыханием» зала с его неуловимым воздействием на актера, воспринимаемым шестым чувством. Поистине, условна эта «четвертая стена». Такова общая атмосфера сценического действа, весьма благодатного для стихийного буйства бессознательного - непостижимого без аналитического участия психологии.

Мы говорим - актер играет. В определенном смысле это так. В известной психологической науке общей классификации теории игр театр относится к «игре-подражанию». Не случайно в театральный лексикон издавна вошли такие понятия, как лицедейство, личина, маска, двойничество. Но характерно, педагоги по актерскому мастерству чаще говорят: «Актер проживает». Пожалуй, так точнее. И проживает он не две жизни, а одну, не раздвоенную. Ибо творчество для него - это самоактуализация через перевоплощение в другого. Здесь уместно сослаться на Ежи Гротовского, остроумно заметившего, что сцена - это единственное место, где актер не играет. Парадоксально, но с глубоким смыслом.

Театр сродни другим исполнительским искусствам слитностью бытийности произведения с процессом его сотворения. Другие признаки их общ- 
ности, либо отсутствуют, либо их нет. Нет «четвертой стены», двойничества, сопряженности «Я» и «другой», нет полноты органичного проживания, экзистенционального существования. Совершенно очевидно, прерогативой какой области знаний это является.

Другое решающее обстоятельство, делающее неизбежным психологическое измерение творческого процесса театрального искусства, обусловлено уникальностью его языковых средств художественного выражения и воздействия. В искусстве, вообще, имеет место, пожалуй, основная трудность художественного письма, которое проявляется в не всегда адекватной реализации мыслей и чувств художника. Его неудовлетворенность и «муки творчества» по этому поводу обстоятельно описаны Гегелем в его «Лекциях по эстетике». Вспоминается здесь и широко известное тютчевское: «мысль, изреченная есть ложь». О нетранспарентности между содержанием, мыслью, с одной стороны, и способом их выражения, с другой, также писал и Ф. де Соссюра.

По причине широких звуковых и изобразительных характеристик театрального языка его выразительные возможности исключительно богаты. Они достаточно универсальны в свой способности неявно взаимодействовать с аудиторией спектакля. При всем том, что общение на сцене происходит между персонажами спектакля, подлинным адресатом является зритель, живо реагирующий на каждое слово актера, его движения, жесты, мимику, интонацию голоса, подчас, напрямую обращенные к нему.

Надо заметить, что вербальный язык составляет не более $30 \%$ языка нашего общения. Основная доля приходится на несловесные способы коммуникации, которые составляют богатую палитру изобразительно-выразительных средств актера. Понятно, как высока должна быть психотехническая культура актера, чтобы овладеть всем арсеналом коммуникационных возможностей. Однако даже при таком их разнообразии до конца объективировать (опредметить посредством языка) глубинные слои содержания весьма проблематично. Дело в том, что мы сознаем видимое и слышимое, но это не гарантирует проникновения в смысл осознаваемого. В значительной степени он угадывается бессознательно, интуитивно, ассоциативно.

М. Хайдеггер пишет: «Осмыслением подразумевается больше, чем просто осознание чего-либо. Мы еще далеки от осмысления, пока просто чтото сознаем. Осмысление требует большего. Оно - отданность достойному вопрошания» (Хайдеггер, 1993: 251). В случае с искусством «достойна вопрошания» психология языка, межличностных отношений, конфликта, ассоциативного мышления, аффекта... Здесь неприложим логико-понятийный метод анализа и осмысления. Смыслотворчество актера следует не правилам, а мотивам - мотивам поведения, поступка, развития характеров 
и обстоятельств. Не логическая закономерность, и не соответствие истине, а внутренне обоснованная мотивация является оправданием «игры воображения» (И. Кант).

Здесь эпистемология уступает место герменевтике, своего рода ответвлением которой является так называемая «Понимающая психология». Методологические принципы этого направления современной психологической науки ориентированы не столько на познавательные цели, сколько на постижение духовного содержания, безотносительно того, задано оно сознанием, «здравым смыслом» или безудержной игрой воображения и вымысла.

Психология служит мотивации, пониманию и объяснению проблемных драматических ситуаций, сюжетных коллизий, конфликтов, парадоксальных обстоятельств, непредвиденного развития характеров и действия. Одна из значимых особенностей спектакля заключается в том, что, изначально воздействуя на зрителя, он вызывает усиленную психологическую рефлексию. Такой характер воздействия максимально активизирует чувственно-эмоциональную сферу воспринимающего. В результате, он вслед за актером интенсивно проживает, происходящее на сцене.

Далее представляется целесообразным привести развернутый перечень вопросов, рассмотрение которых может быть плодотворным только в аспекте методов и подходов психологической теории. Это сделает более конкретным и предметно определенным содержание данной статьи, актуализирует задачу в ней поставленную. Сами вопросы предельно кратко сформулированы и представляют собой основную проблематику психология творчества:

- Потребность в искусстве;

- Побудительные мотивы творчества;

- Истоки и факторы художественной деятельности;

- Искусство как преодоление (Л. Выготский) и приращения реальности;

- Характеристика одаренности и предрасположенности к актерской профессии;

- Самоактуализация в творческом процессе;

- Художественное произведение - универсальная форма опредмечивания личности;

- Снятие противостояния объективного и субъективного;

- Понятие личностного смысла;

- Биосоциальная природа таланта и гения;

- Влияние художественного творчества на психофизиологические процессы;

- Трансформация сознания из обыденного в художественное; 
- Природа художественного переживания; ного;

- Взаимообусловленность чувственно-эмоционального и рациональ-

- Эмпатия, «вчувствование», «умные эмоции»;

- Преднамеренность «случайностного» фактора в творчестве;

- «Видимость» и «кажимость» (Ф. Гегель) сценического действия;

- Соотношение сознательного и бессознательного (в репетиционный и собственно творческом периодах);

- Психоаналитическая концепция (3. Фрейд);

- Архетипы и коллективное бессознательное (К. Юнг);

- Мотивировка художественно-образной системы;

- Алогизмы, парадоксы сюжетно-фабульных связей;

- Принцип антитезы и противочувствия;

- Эффект остранения (В. Шкловский) и очуждения (Б. Брехт);

- Психология катарсической рефлексии;

- Психологическая подоснова приемов комбинирования и акцентирования;

- Понятие эстетической дистанции;

- Обособление и отождествление своего «Я»;

- Ассоциативное мышление и синестезия;

- Феномен психологической установки (школа Д. Узнадзе);

- Психологическая и гносеологическая обусловленность художественного восприятия;

- Феномен перформанса в сценическом искусстве;

— «Психологический театр переживания» (К. Станиславский) и «Театр представления» (Б. Брехт);

- Психологический анализ жанрового многообразия драматургического материала;

- Игровая природа искусства.

Заметим, что данный блок вопросов может быть представлен в качестве инвариантной модели курса по психологии творчества. Его иные версии вполне правомерны, более того - желательны, учитывая сложившуюся художественно-эстетическую традицию различных театральных школ.

\section{СПИСОК ЛИТЕРАТУРЫ}

Хайдеггер, М. (1993) Время и бытие: статьи и выступления. М. : Республика. 
Оганов Арнольд Арамович - доктор философских наук, заведующий кафедрой философии и культурологии Высшего театрального училища (института) им. М. С. Щепкина. Адрес: 109012, Россия, г. Москва, ул. Неглинная, 6/2, стр. 1,2. Тел.: +7 (495) 624-52-25. Эл. адрес: schepkinskoe@theatre.ru

Oganov Arnold Aramovich, Doctor of Philosophy, Head, Department of Philosophy and Culturology, Mikhail Shchepkin Higher Theatre School (Institute). Postal address: 6/2, Bldg. 1, 2, Neglinnaya St., Moscow, Russian Federation, 109012. Tel.: +7 (495) 624-52-25. E-mail: schepkinskoe@theatre.ru

\section{Для цитирования:}

Оганов А. А. Проблематика психологии творчества в театральном искусстве [Электронный ресурс] // Научные труды Московского гуманитарного университета. 2018. № 3. URL: http://journals.mosgu.ru/trudy/article/ view/738 (дата обращения: дд.мм.гг.). DOI: 10.17805/trudy.2018.3.1 